\title{
The Construction and Promotion of the Theoretical System of Marxist Politics - Summary of Wang Huiyan's Political Thoughts
}

\author{
Xuanming Zhang \\ School of International Relations, Renmin University of China, Beijing 100872, China \\ Email:453515894@qq.com
}

\begin{abstract}
Mr. Wang Huiyan is the leader of contemporary Chinese Marxist politics, and has made outstanding contributions to the Chinese characteristics, Chinese style and Chinese style formed by Chinese politics. Mr. Wang's political thoughts have always been guided by Marxism, and China's national conditions have always been the starting point for political studies. He creatively proposed the Marxist political theory system and principle curriculum system with state power as the core, and developed It has established important theories such as the construction of socialist democracy and legal system with Chinese characteristics. Mr. Wang's theoretical system of Marxist politics has been vigorously promoted by the academic circles and has made outstanding contributions to the construction of socialism with Chinese characteristics. Keywords: Wang Huiyan, Marxist politics, theoretical system
\end{abstract}

Mr. Wang Huiyan is a famous political scientist and jurist in China. He has always adhered to Marxism and the party's leadership, firmly believes in the cause of the Chinese Communist Party, and firmly believes that socialism is the only way out for China. In 1978, Mr. Wang founded the Department of politics of Jilin University and served as the first head of the department. Mr. Wang is committed to the study of Chinese politics system with Chinese characteristics, researching and summarizing the basic theories of Marxism and politics, creating the theoretical system and curriculum system of contemporary Chinese Marxist politics, and reconstructing contemporary Chinese politics And development has made a significant contribution. His academic thoughts and scholarly spirit promote and inspire the continuous development and advancement of Chinese politics.

\section{Have firm beliefs and develop the theoretical system of Marxist politics}

As a leading figure in contemporary Chinese politics, Mr. Wang Huiyan's solid theoretical foundation is closely related to and inseparable from Marxist beliefs. It is precisely because of this belief that Mr. Wang has gone further and further along his bumpy academic road. After Mr. Wang has experienced all kinds of hardships unimaginable by ordinary people, his persistence and belief in Marxism have become more firm and conscious. The fundamental reason lies in Mr. Wang's in-depth research and understanding of the basic theories of Marxism. At the beginning of the establishment of the Department of politics at Jilin University, Mr. Wang proposed the policy of running the department. The first is to adhere to the guidance of Marxism.

Mr. Wang not only adheres to Marxism, but also emphasizes that politics is applied research. He believes that it is necessary to integrate theory with practice, establish a political outlook with Chinese characteristics; advance with the times, combine Marxism with the characteristics of the times, develop and innovate Marxist politics, and take the development of Marxism as a major task of politics research. Mr. Wang often said, "Develop Marxist political theory in the process of adhering to Marxism, and adhere to Marxism in developing Marxist political theory." ${ }^{[1]}$ Therefore, the main source of his political outlook is Marxism.

Regarding the overview of politics, classic Marxist writers have not given a specific definition, but they have made more profound explanations from other aspects and angles. "All class struggles are political struggles." [2] "Politics is a struggle between classes." [3] "Politics, whether revolutionary or counter-revolutionary, is a class-to-class struggle, not the behavior of a few individuals. " ${ }^{[4]}$ From these Marxist classic writers' related discourses on politics, Mr. Wang summarized politics as a kind of class relationship and regarded political power as a key part. Its activities are science and art. Mr. Wang clearly pointed out: Politics is a science that studies the existence of classes, takes the state as the main body of research, and summarizes the political phenomena and social relations and the laws of operation in it.

Mr. Wang's political outlook is concentrated in his national outlook. A series of conceptual principles such as class, party, state, and regime in the principles of politics are also expounded around the principle of state. The emphasis of Marxist politics is on the state and state power. On this basis, Mr. Wang regards the state and state power as the focus of 
studying the nature and laws of contemporary Chinese political phenomena, and makes full use of Marxist viewpoints to explain. "The core of politics is state power. Whether it is a society with classes or a society in which the people hold power, the existence and resolution of various political relationships are achieved through state power." ${ }^{[5]}$ He is based on these theories. , Established a national political view, and then established a political theory system with state power as the core element.

The first is the origin theory of the state. The Marxist state theory points out that the state does not appear until the social productive forces have developed to a certain extent. The origin of a country can determine the nature of a country. People of the exploiting class will give various answers according to the interests of their class and the actual situation. There is a fundamental difference between Marxist politics and the politics of exploiting classes. Mr. Wang pointed out that the social system is determined by human production and material production. It is not the promotion of external forces that produces the state. In the final analysis, the change and development of material production in society and human production produced the state. On the one hand, this thought strongly criticized the theocratic theory of feudal society, the contract theory of capitalist society, and the theory of violence on the origin of the state. On the other hand, this theory can fully integrate theory with reality, and has a profound understanding of the changes in the social structure of today's China.

The second is the essence theory of the state. Mr. Wang combined theory with reality, based on Engels's thesis, combined with my country's national conditions and development needs, and made a more in-depth judgment on the nature and role of the country. The primary condition for the emergence of a country is the inevitable nature of class contradictions. The purpose of the emergence of the country is to alleviate this conflict. The order discussed by Engels is the regular operation of social activities. In China, the first manifestation of order is stability. Stability is the prerequisite for development and progress. The stability of China is to safeguard the fundamental interests of the people. This is the nature and role of the state pointed out by Marxism, and is the inherent requirement of the nature of a socialist country.

The third is the state's demise theory. The state emerged in order to be able to alleviate social conflicts. But when the productive forces are sufficiently developed and in a communist society, there is no longer a need for conflict-relieving management groups. ${ }^{[6]}$ The inherent advancement of socialist countries has determined the difference from Western capitalist countries. The essence of socialist countries is the dictatorship of the proletariat. It is not just a tool of the ruling class to ease conflicts, but also to build socialism and serve. A tool for realizing communism to create material and spiritual conditions. ${ }^{[7]}$ Therefore, as the last historical type of country in human history, the socialist country will only evolve and will not die out in a short period of time, and its essence will not change.

\section{Combine theory with practice to create a Marxist politics curriculum system}

In order to meet the needs of China's reform, opening up and development, after the Third Plenary Session of the Eleventh Central Committee of the Communist Party of China, the country proposed to resume the construction of politics. "But at the time, there was a huge shortage of talents in Chinese politics. In a huge China, only 23 people who had a certain degree of research on politics were found. It was these 23 people who provoked the burden of the development of Chinese politics. Among these 23 people, Most of them are old gentlemen with white temples." ${ }^{[8]}$ At that time, Mr. Wang, as the youngest scholar among them, naturally carried the heaviest burden. In order to make up for the gaps in the curriculum construction and textbook construction of politics, Mr. Wang has worked hard to study and write on the basis of many years of politics research and teaching practice, and systematically published "Principles of politics", "Administrative Management" and "Leadership". Science, Basic Theory of Law, Basic Theory of Contemporary politics and more than 20 books and textbooks. In political theory, he clarified the basic theory of state power, the law of development of state power, the structure and organizational form of state power, the general structure of state politics (political governance system), state institutions, political parties and political organizations, politicians, and politics. Important content such as leadership and decision-making.

The political theory system created by Mr. Wang takes state power as its core and Marxism as its guiding ideology. It uses the basic positions, viewpoints and methods of Marxism to determine the connotation and extension of political phenomena, and to determine the basic content framework of political principles. Formed the basis of the course system of politics principles. Starting from the Marxist political view, choosing politics topics with theoretical significance, and taking the Marxist national theory as the core, forming an organically connected whole, it is Mr. Wang's full use of the Marxist political view. Mr. Wang created the politics theoretical system to meet the needs of politics teaching. This is also related to whether the politics talents cultivated by China can serve socialist political construction and political development. The establishment of this system conforms to the basic principles of Marxism, suits the needs of contemporary Chinese political development, captures the essence and core of political phenomena, and embodies the characteristics of political 
phenomena as an organic whole and a dynamic process. At the same time, Mr. Wang pays attention to absorb and learn from the latest achievements of contemporary Western politics research. After the establishment of the politics principles curriculum system, Mr. Wang also raised the issues that need attention in the application of the system.

First, when using the curriculum system, we must implement the principle of combining theory with practice, so that students can understand and master major international and domestic political issues in reality, and can use basic political theories to understand and analyze these issues. If we leave this point, the principles of politics have no theoretical guiding significance and become dogma. Mr. Wang always emphasized that in order to integrate theory and practice in political research, it needs to be based on the needs of today's society. If it is out of touch with the needs of society, it will inevitably lead to the hollowing out of politics research. Mr. Wang pointed out that the prerequisite of politics research should be based on the fundamental principle of serving reality. Whether it is the research of politics or the academic growth of individuals, the question of direction is the most important. Therefore, going deep into China's national conditions and facing real problems have become the purpose and philosophy of Mr. Wang's teaching and research for decades. Therefore, it is very important to adhere to the integration of theory and practice to apply the politics principle curriculum system, and the politics principle curriculum system will also be tested, enriched and developed in this process.

Second, it is clearly pointed out that the curriculum system of the principles of politics is not fixed once it is established, and should be continuously improved. Otherwise, the curriculum system will become obsolete, lag behind the development of the theory of the times, and then be eliminated. As for the absorption of new results, Mr. Wang believes that it is entirely possible to learn from the West. But be careful not to eat the foreign. The Chinese will speak Chinese. The study of politics in Western countries cannot be overwhelming. The important thing is to fully understand the meaning inside and then express it in your own way. This is the embodiment of "Chinese dialect". If it is all expressed in a way that makes people difficult to understand, it seems that the study of politics is quite deep, but after all, it is just copying. For these scholars who are keen to evaluate Chinese politics with Western theoretical perspectives, Mr. Wang pointed out the problem. These scholars did not keep in mind the most basic principles of Marxism and did not apply them flexibly, so they broke away from the politics of Marxism. His research can't explain China's problems even more, and it loses the fundamental significance of the existence of the system.

Third, when teaching politics theories, we must deeply grasp the basic theoretical essence of the politics curriculum system, and focus on cultivating students' theoretical thinking ability in understanding and solving problems. The curriculum system created by Mr. Wang is to serve students. Mr. Wang's curriculum system is a system with internal logical connections, in which various categories, concepts, and contents are organically connected and logically unified. Mr. Wang has repeatedly emphasized that when teaching politics principles, the content of each chapter and section cannot be understood in isolation, but the content of each part should be connected and understood, and the core and logical thinking of the curriculum system should be grasped. Basic theory and methodology courses are the two parts of the system. Mr. Wang expects students to train their thinking skills and improve their methodological quality while learning the basic theories of politics. Only in this way can we achieve the true purpose of teaching politics principles.

\section{Pay attention to Chinese characteristics and innovate the theoretical research of Marxist politics}

The theory of democracy and legal system is an important content of politics research, and it is also the main argumentation point of Chinese politics and western politics. In the theories of democracy and legal system, Mr. Wang Huiyan not only clarified the connotation, characteristics, form, conditions and essence of democracy and legal system, but also pointed out the direction and characteristics of Chinese politics research, and further proposed that the current Chinese political civilization is being constructed. The main problem that needs to be faced.

In the series of articles such as "On Democracy and Legal System", "Deng Xiaoping's Theory on Socialist Democracy", "Deng Xiaoping's Theory of Democracy and Legal System", and "Building Socialist Democratic Politics with Chinese Characteristics from the Reality", Mr. Wang proposed that socialist countries should Democracy and the legal system have determined its unique position in the international arena, which is far different from democracy in other countries. Mr. Wang pointed out that democracy is an important basis for the legal system, and it also determines the nature and content of the legal system. Before expounding the legal system with Chinese characteristics, we should give priority to expounding the democracy with Chinese characteristics. The Chinese characteristics here refer to the difference in Western democracy compared with the current international mainstream and the advanced nature of Chinese characteristics. "Any democracy, like any political superstructure in general, serves production in the final analysis, and in the final analysis is determined by the relations of production in the society." ${ }^{[3]}$ Therefore, Western democracy in 
contemporary capitalist countries is the bourgeoisie The purpose of democracy is to realize and protect the fundamental interests of the bourgeoisie. On the other hand, socialist democracy with Chinese characteristics is a democratic system led by the Communist Party and based on democratic centralized production. The essential difference between the two democracies is attributed to the division of classes, and the most important thing is the different national conditions. These two aspects determine that China's democracy and legal system have distinctive Chinese characteristics.

Democracy is concrete. Mr. Wang emphasized that "if all members of society enjoy democracy, then democracy will not exist." ${ }^{[6]}$ For those who cannot enjoy democracy, it is necessary to implement dictatorship. This is the combination of democracy and dictatorship proposed by Marxism, and the two cannot be separated. And the socialist dictatorship is not violence, but a way to realize the interests of the overwhelming majority of the people. It can be seen that China's democracy does not include the democracy of all people, but the democracy of the broadest people. Therefore, compared with other capitalist countries pursuing democracy for all, China's democracy is not so abstract and empty. On the contrary, China's democracy is real. It is a concrete people's democracy, so that the majority of the people can benefit from it. This is the biggest feature of Chinese democracy.

The legal system is a system that raises the will of the ruling class into law and regulates the observance and execution of the members of the society. In other words, the legal system is that state agencies formulate relevant codes of conduct based on the fundamental interests of the ruling class to guide members of society on what they can and cannot do. Everyone must enforce them, and those who violate them will be punished. Democracy is a part of the democracy defined by the ruling class with a range of members. The legal system embodies the will of the ruling class. The legal system with Chinese characteristics reflects the interests and wishes of the broad masses of people. And, "When the law conflicts with the personal will of the leader, the law is higher than the individual's will, not the individual's will is higher than the law." [9] This is what Mr. Wang obtained through the comparison and research of the legal system and the rule of man. The inner meaning of the legal system. Mr. Wang also pointed out that the rule of law and the construction of a socialist country under the rule of law include laws to follow, law must be followed, law enforcement must be strictly enforced, and violations must be investigated. This is the form of the realization of the socialist legal system. This form reveals that the fundamental method of governing the country is to use the law, and it is to uphold the authority of the law that reflects the opinions of the broad masses in the country's politics, economy and society. This is a sign of the progress of social civilization in our country. Mr. Wang is closely related to the characteristics of the modernization of socialism and the development of reform and opening up, and with his unique vision, he gives theoretical answers to the esoteric problems that have attracted much attention in current political research.

The operation of Chinese democracy requires proper handling of some relationships. "We must combine democracy over the people with dictatorship over the enemy, and unite democracy and centralism, democracy and the rule of law, democracy and discipline, democracy and party leadership." ${ }^{[10]}$ It is China that properly handles these relationships. The prerequisite for the orderly operation of characteristic socialist democracy. The only way to fully express the wishes and demands of the people is to realize socialist democracy, and the socialist legal system is to guarantee democracy. The basis and content of the current Chinese legal system are determined by democracy with Chinese characteristics, and the Chinese legal system is the embodiment of Chinese democracy. "The process of expanding and improving socialist democracy is actually a process of continuously strengthening the socialist legal system." ${ }^{[1]}$ Thus, the relationship between democracy and the legal system is inseparable. The Chinese legal system based on democracy with Chinese characteristics also has distinctive Chinese characteristics.

Real and concrete democracy is to achieve institutionalization and legalization, while the legal system is the expression of democracy. The will of the people of socialist democracy and the legal system is the supreme will. Equality before the law is a prerequisite for realizing the will of the people. Mr. Wang pointed out that the democracy and legal system with the most Chinese characteristics is the democracy and legal system under the leadership of the Communist Party. "The essence of the democratic rights of the broad masses of people is to mobilize the enthusiasm and creativity of the broad masses of people to jointly build the great cause of socialist modernization." ${ }^{[12]}$ The leadership of the party can effectively concentrate the power of the broad masses, and it is also what the people want. Therefore, the leadership of the Chinese Communist Party is also a prerequisite for democracy with Chinese characteristics. At the same time, Mr. Wang proposed that the legal system with Chinese characteristics stipulates that the constitution and laws are the supreme will. China's socialist democracy and legal system are under the leadership of the party and embody the will of the people under the leadership of the party. The socialist democracy and legal system also strengthen the party's leadership, make the party's leadership more standardized and serve the people more effectively. The biggest feature of China's socialist democracy and legal system. 
The main problem in the construction of contemporary China's political civilization is to strengthen the construction of China's state power and to further promote the implementation of the rule of law policy. Mr. Wang clearly stated that the theory of state power is the fundamental theory in Marxist politics. Only with the guarantee of a stable state power can we better build socialism. To build a socialist political civilization, it is necessary to use the rule of law instead of the rule of man. In the final analysis, it is the rule of law. The construction of socialist political civilization is to enable the value superiority of Chinese democracy to be fully implemented and brought into play through the improvement of various systems. The system of China's democratic politics needs further development on four levels. The first is the system of people's congress; the second is the system of ethnic regional autonomy; the third is the system of civil autonomy and grassroots democracy; the fourth is the system of multi-party cooperation and political consultation under the leadership of the Communist Party of China. Mr. Wang's theory of the construction of socialist political civilization is based entirely on China's actual national conditions and has made significant ideological contributions. Mr. Wang's series of theoretical contributions to the political development of contemporary China have been widely praised by the politics community, and have also been highly recognized by the country. Entrusted by the former State Education Commission or the Ministry of Education, Mr. Wang was responsible for drafting consultation reports on Chinese politics from the "Seventh Five-Year Plan", "Eighth Five-Year Plan", "Ninth Five-Year Plan" to the "Tenth Five-Year Plan", etc., leading to the development of contemporary Chinese politics.

\section{Conclusion}

Mr. Wang Huiyan has a firm belief in Marxism, creatively put forward the theoretical system and curriculum system of Marxist politics, and made innovative explanations and answers to several important theoretical issues facing contemporary Chinese politics. He is the leader of contemporary Chinese Marxist politics. The politics teaching and research situation with Chinese characteristics, Chinese style and Chinese style formed under the advocacy and promotion of Mr. Wang is not only the credit and honor of Mr. Wang, but also the pride and pride of the Chinese politics community. Mr. Wang's unswerving rational beliefs, innovative spirit of advancing with the times, profound theoretical courage, and optimistic and open-minded attitude towards life have guided Chinese political scholars and are the development theory of Chinese Marxist politics. Demonstrations and methodological guides lead the pioneering and enterprising of Chinese politics.

\section{References}

[1] Zhang Xianming. The demeanor lasts forever, and the spirit inspires future generations — remembering and promoting Mr. Wang Huiyan's academic thoughts. politics Research. 2008; (1): 2.

[2] Bureau of Compilation and Translation of Works by Marx, Engels, Lenin and Stalin, Central Committee of the Communist Party of China. Selected Works of Marx and Engels (Volume 1). Beijing: People's Publishing House; 1972.

[3] Bureau of Compilation and Translation of Works by Marx, Engels, Lenin and Stalin, Central Committee of the Communist Party of China. Lenin's Selected Works (Volume 4). Beijing: People's Publishing House; 1972.

[4] Mao Zedong. Collected Edition of Selected Mao Zedong. Beijing: People's Publishing House; 1968.

[5] Wang Puhuo. Analysis of Mr. Hui Yan's Political View - Remembrance of the 5th Anniversary of the Death of Mr. Hui Yan. Journal of Social Science of Jilin University. 2012; (5): 69.

[6] Han Dongxue. Professor Wang Huiyan's academic achievements and academic thoughts. Theoretical Front of Universities. 2003; (8): 25.

[7] Wang Huiyan. Wang Huiyan Collected Works (Volume 1). Beijing: China Encyclopedia Publishing House, Party Building Reading Material Publishing House; 2007.

[8] Wang Shujun. Pioneer in the field of politics-a record of my country's famous political scientist and jurist Professor Wang Huiyan. Social Science Front. 1997; (4): 255.

[9] Wang Huiyan. Wang Huiyan Collected Works (Volume 2). Beijing: China Encyclopedia Publishing House, Party Building Reading Material Publishing House; 2007.

[10] The Document Editing Committee of the CPC Central Committee. Selected Works of Deng Xiaoping (Volume 2). Beijing: People's Publishing House; 1994.

[11] Jilin University School of Administration. Wang Huiyan Memorial Collection. Beijing: People's Publishing House; 2013.

[12] Wang Huiyan. On Democracy and Rule of Law. politics Research. 2000; (3): 10. 